\title{
TARDAR SEIM AND THE HISTORY OF A NORWEGIAN-ROMANIAN STORY
}

\section{Crina Leon}

Alexandru Ioan Cuza University of Iaşi, Email: crina_laurentiu@yahoo.no

\begin{abstract}
Jardar Seim is a historian and member of The Norwegian Historical Association, a specialist in Eastern European history which he taught at the University of Oslo between 1983 and 2002, and moreover a keen speaker of the Romanian language. $\mathrm{He}$ is the author of the works Øst-Europas historie/The History of Eastern Europe (Aschehoug, Oslo, 1994) and ØstEuropa etter murens fall/Eastern Europe after the Fall of the Wall (Aschehoug Forum, Oslo, 1999) and co-editor of the book Romanian-Norwegian Relations. Diplomatic Documents, 1905-1947 (Romanian Cultural Institute, Bucharest, 2007), one of the very few works dealing with the Norwegian-Romanian diplomatic relations. He was also a teacher of history, Norwegian and social studies at the High School in Ski, Norway, and responsible for the pupils' exchange between the above-mentioned high school and Unirea High School (later Unirea National College) in Braşov, Romania, in the period 1993-2008.
\end{abstract}

\section{Rezumat}

Jardar Seim este istoric şi membru al Asociației norvegiene de istorie, specialist în istoria Europei de est, disciplină pe care a predat-o la Universitatea din Oslo între 1983 şi 2002 şi, mai mult decât atât, un vorbitor pasionat de limbă română. Este autorul lucrărilor Øst-Europas Historie/Istoria Europei de Est (Aschehoug, Oslo, 1994) şi Øst-Europa etter murens fall/Europa de Est după căderea Zidului (Aschehoug Forum, Oslo, 1999) şi co-editor al cărții Relații româno-norvegiene. Documente diplomatice, 1905-1947 (Institutul Cultural Român, Bucureşti, 2007), una dintre foarte puținele lucrări care abordează relațiile diplomatice dintre Norvegia şi 
România. A fost, de asemenea, profesor de istorie, norvegiană şi sociologie la Liceul din Ski, Norvegia, şi responsabil pentru schimbul de elevi dintre liceul mai sus-menționat şi Liceul (ulterior Colegiul Național) Unirea din Braşov, România, în perioada 1993-2008.

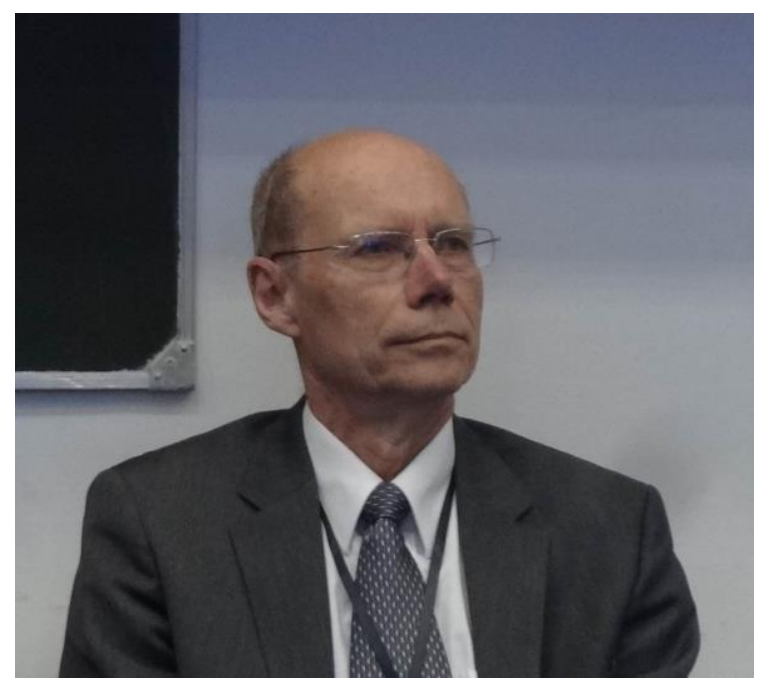

Photo: Crina Leon

\section{How did you get to discover Romania, such a distant country from} Norway?

It is not easy to figure out how a certain interest originated many years ago. But in this case I am fully aware of how a spark was aroused in me. Sometime in the 1960s I was passively listening to a music program on the radio. Suddenly the music started vibrating in a way I had never heard before. I was fascinated by the changes from a sore, melancholic tune to ardent, rapid movements. In other words, I had made my first acquaintance with Romania through its fabulous folk music. I even managed to order the LP that I had been listening to. I still have it. After that I set out to enlarge my former scarce knowledge about Romania by some reading, discovering for instance the surprising existence of a Romance language in the eastern part of Europe. 


\section{What memories do you still keep from your first visit to Romania, in 1965?}

My first visit to Romania was in 1965-66 and lasted for nine months. After participating in summer courses for foreign students in Sinaia, I stayed for eight months in Bucharest studying at the University. That was owing to the first cultural agreement between Norway and Romania, which included scholarships for a student exchange. I was the first Norwegian student to make use of that. But the Romanian student who was supposed to arrive in Norway, never showed up. Responding to your question, I could pick out many memories from that year. Let me just mention two. Not everyone around me at home in Norway was convinced that it was wise of me to go to a communist country for such a long time. It turned out that I was the only Norwegian resident in Romania at that time, and there was no Norwegian embassy there, only in Belgrade. Before leaving Norway somebody warned me of the never-ending communist propaganda I would be exposed to all the time. I laughed at that. Of course I knew that I was to stay in a communist dictatorship with no freedom of the press, only one political party and a certain surveillance by the secret police. But I was confident that this was only part of the whole picture. I would also meet normal, ordinary people and get better knowledge of various aspects of the Romanian culture. With this conviction in mind I was nearly knocked out by one of my first experiences upon my arrival in Sinaia in July 1965. Suddenly I realized that there were loudspeakers on the main street spitting out political propaganda, even if I didn't understand the words. A mood of distress overtook me. Were the warnings correct after all? Should I live in a political loudspeaker-hell for almost one year? Luckily, I should not. This arrangement was made on a special occasion, the 9th congress of the Romanian communist party when Nicolae Ceauşescu was officially elected general secretary. Another memory: The lecturing by the university professors in Bucharest would always be constrained within the party's political confines. Nevertheless, sometimes there might be a surprise. Not in a large auditorium, of course. One of the surprises that I experienced came in a small introductory language group for foreign students. At the 
end of a session our teacher told some of us, I don't think the whole group, about a Romanian writer who had been high up in the communist literary apparatus, before defecting to the West in 1960. All his works were removed from the libraries and bookshops. His name was Petru Dumitriu. His last book at that time was "Incognito". It had appeared in French in Paris in 1962, and an English translation followed in 1964. I bought it immediately when I returned to Norway in 1966. It is a fascinating novel about the first years in Romania after the Second World War, falseness and deception being central themes. Unfortunately, I have forgotten the name of this daring professor who pointed to a forbidden writer.

\section{What attracts you most to Romanian history?}

There are many interesting periods in the Romanian history. Personally, I think that the interwar period is one of the most interesting. Sometimes I have heard Romanians, not historians, by the way, describing it in a rosy, almost panegyrical way. In the communist historiography it was mostly the other way around. What attracts me to the interwar history of Romania, however, is not that it has been contested, but that it was so varied, so rich in possibilities, crossing influences, power and powerlessness, and with contrasting views of how a society should be understood and developed. Firstly, Romania shared many of the common European preconditions for that period, like the aftermath of the First World War, the great economic depression and the new militant ideologies. Secondly, Romania had its own characteristics and conflict lines from before the war, continuously playing a role, like the problems of the peasantry, the different attitudes towards industrialization, or the priorities in the foreign policy. And thirdly, there were the actual political institutions, the social structures, the mentalities and not to forget, the people. Ordinary, anonymous people that sometimes behaved collectively also in a political setting, like the participants in the large demonstrations against the liberal government in 1928. Or individuals that more or less singly were in a position to change a direction or lay new premises for the future, like some politicians or king Carol II. In this interplay of external and internal, structural and personal factors in a specific time there are many fascinating details 
that also invite explanations and drawing of larger lines, thus enriching the general understanding of Romanian history.

Could you identify some common features between the history of Romania and Norway?

I find it a bit artificial and too programmatic to look for common features between the history of Romania and Norway. But there are many fields where comparisons may be meaningful and open up for new understandings of both countries. One could, for instance, compare on a regional level different cooperative institutions in the countryside in the interwar period. Or one could compare how the two countries defined their positions in NATO and the Warsaw pact during the Cold War, both of them with some sort of deviation from the standard conduct of member states.

Bjørnstjerne Bjørnson was not just a Nobel Prize laureate in literature, but he was also related to Transylvania. How important do you consider him both for the history of Transylvania and for Norwegian history?

Bjørnstjerne Bjørnson was very important for Norway, both as a prolific writer and as a political person, engaging himself in a great many subjects. Not as an ordinary politician, but rather as a prophetic and rumbling voice that made both friends and enemies around him. He also had a European reputation and used that in his commitment for suppressed peoples. He condemned Hungary's policy of magyarization in Slovakia, and when he became aware of the parallel situation in Transylvania he expressed open sympathy for the Romanians there through a series of interviews in the Romanian-language paper "Tribuna" in Arad.

How do you manage to keep contact with the Romanian language and culture?

I try to keep in touch with Romanian culture in several ways. When visiting Romania I meet friends, but I also try to see places where I have never been before and where I know no-one. An 
example: I had passed by Ploieşti many times on my way from Bucharest to Braşov, but never stopped there. Finally I decided to do that and found Ploieşti well worth a visit. Some reading of the town's history beforehand added to the value of the visit. Last year I rented a car to visit Caracal and Alexandria as well as to look for some former manor houses in the countryside. Such trips broaden the view of what Romania is like. When visiting Romania I also buy far more books than I have got time to read. And of course, the Internet has made a tremendous difference when it comes to being in contact with the culture of a country that is geographically far away.

Since you are a friend of Romania, could you please tell us more about the Norwegian community of Romania's friends?

In the first years of my acquaintance with Romania this question would have been easy to answer, the number of us being so small. Today the situation is much more complex. A great many Norwegians consider themselves friends of Romania, former students, people with professional contacts, tourists who have experienced that Romania is more than Dracula and "Ceauşescu's palace", and so on.

How strong are the bilateral relations between Romania and Norway nowadays?

I consider the relations to be strong, how strong it is impossible to measure. But the official relations are stable and closely knit. And then come the many human bonds. They may be invisible for others than those involved personally, but they are nevertheless sort of a foundation wall in the relations between the two countries, be it through Norwegians with an interest in Romania, or Romanians working in Norway or studying Norwegian at Romanian universities.

In 2014 Romania and Norway celebrated 50 years since they decided to raise their diplomatic representations at the level of 
embassy. Could you please tell us some facts related to the history of the diplomatic relations between our countries?

The diplomatic relations between Romania and Norway are older than the establishment of embassies or legations. Before 1905, when Norway obtained its full independence by the dissolution of the union with Sweden, diplomatic matters were dealt with by the legations of Romania and Sweden/Norway in Berlin. After the dissolution the Romanian government proposed that the existing arrangements should be continued. The proposal was accepted by Norway, and one of the first matters dealt with was Norway's proposal in 1907 for a commercial treaty. This was negotiated and signed in Berlin in 1910. The first permanent diplomatic representation was a Romanian legation in Kristiania (Oslo) in 1917. It was closed for financial, not political, reasons in 1922 and reopened in 1934. Norway established a permanent diplomatic representation in Bucharest in 1935. Later on there were shifting ways of maintaining the relations, for several years through side accreditations in neighboring countries, a token of relatively sparse and limited relations. In that perspective the diplomatic activities were mirroring the general levels of political, economic and cultural connections between the countries. But sometimes individual efforts by skilful diplomats could broaden and deepen the relations by establishing personal contacts and taking initiatives. I think that the Romanian minister in Oslo from 1934 to 1939, Dimitrie Juraşcu, was one such diplomat. He became a well known and respected representative of Romania in Norway. One of the visible results of his work was a large exhibition of Romanian folk art in Oslo in 1936 with several leading Norwegian cultural personalities in the patronage committee.

How has the image of Romania changed in Norway throughout the years?

For many years the image of Romania was marked by the communist dictatorship of Nicolae Ceauşescu and his stubborn resistance to reforms. After 1989 many Norwegians engaged in relief actions for orphans or deprived villages. When Romania became a member of the European Union, the free movement of people in the 
European Economic Area resulted in making Romanian citizens visible in Norway in new ways, as beggars in the streets and thieves in the courts and criminal statistics. Ignorant and prejudicial Norwegians, and there are quite a few of them despite a general high educational level, tended to associate such impressions with the country of origin, having limited supplementary knowledge of Romania. But most people have realized that such impressions are not representative, and many have their own personal impressions from the many Romanians working in ordinary jobs in Norway. They are not so visible, they integrate into the society, but they are many more in numbers. I would add that a certain negative general image for many years developed independently of the marginal groups just mentioned. I think of the creeping doubt many got concerning the transition period after 1989, when Romania had experienced an all-times high level of sympathy in Norway at Ceaussescu's fall. After 1989 we heard of the "mineriades" and that many former party cadres remained in power disguised as new struck democrats, of the sudden enrichment of some such people, and corruption on a large scale. Of course, the image one develops of another country is also a product of one's own values, there is no neutral way of describing another society. Norway is a country with strong egalitarian values, even if such an expression should not be exaggerated as an absolute. But for many Norwegians the widening gap between rich and poor people in Romania and other former communist countries in the long run will be a more severe threat to the image of the Romanian society than the passing problems I just mentioned. Apart from more or less informed generalizations, I keep to my conviction from the 1960s: Nothing can compare with the image you get by meeting people and getting to know the culture of a country directly. I could never have become a friend of Romania in the stereotyped atmosphere of the Cold War years without such inputs.

[Interview with Jardar Seim, July 4, 2016] 